International Journal of Social Sciences and Humanities
Available online at http://sciencescholar.us/journal/index.php/ijssh
Vol. 3 No. 2, August 2019, pages: $145 \sim 155$
e-ISSN: 2550-7001, p-ISSN: 2550-701X
https://doi.org/10.29332/ijssh.v3n2.306

\title{
Learning Problems on Educational Context for Cascol Parish
}

\author{
CrossMark \\ Carlos Julio Bastidas Martinez a , Brenda Stefania Guale Vasquez b, María Elena Moya Martinez c, \\ María Rodríguez Gámez ${ }^{\mathrm{d}}$
}

Article history: Received 18 December 2018, Accepted: 30 April 2019, Published: 06 August 2019

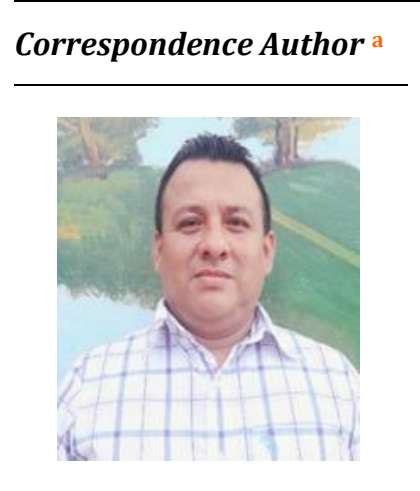

Keywords

acquisition;

context;

education;

learning problems;

psycho pedagogic;

\begin{abstract}
Learning problems have become a relevant topic within the psycho-pedagogical area, referring to problems in language acquisition, reading, and writing or in the numerical area. Students who have learning problems have certain characteristics such as normal or higher intelligence and do not have any sensory deficits. The objective of the work is to know the different learning problems that arise in the students of the educational institutions of the Cascol parish of the Pajàn canton. The paper offers a conceptual analysis of the different learning problems. It has approached from the definition, causes, and consequences where several authors who have studied the subject have analyzed. The ability of teachers to analyze and investigate the problems that generate or cause the blockage in the development of their skills and the importance of psychological support to students who have learning problems to provide strategies to correct and avoid complications in the future has analyzed. The impact on the youth of the parish of Cascol, the importance of knowing the causes and consequences of different learning disorders has analyzed. Finally, the conclusions of the work have exposed, where the relevance of the study has shown to know the different learning problems in adolescents.
\end{abstract}

e-ISSN: 2550-7001, p-ISSN: 2550-701X ๑ Copyright 2019. The Author. SS Journals Published by Universidad Técnica de Manabí. This is an open-access article under the CC BY-SA 4.0 license (https://creativecommons.org/licenses/by-sa/4.0/) All rights reserved.

\section{Contents}

Abstract

1. Introduction.

2. Materials and Methods......

a Pontificia Universidad Católica del Ecuador, Portoviejo, Manabí, Ecuador

b Pontificia Universidad Católica del Ecuador, Portoviejo, Manabí, Ecuador

c Pontificia Universidad Católica del Ecuador, Portoviejo, Manabí, Ecuador

d Universidad Técnica de Manabí, Portoviejo Ecuador 


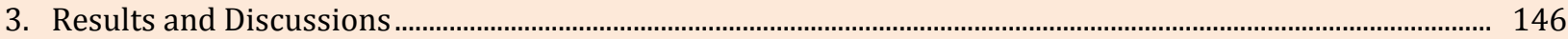

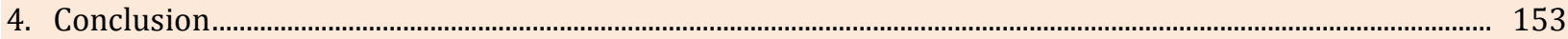

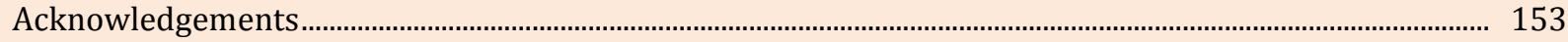

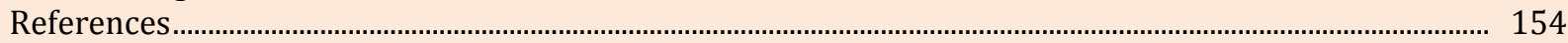

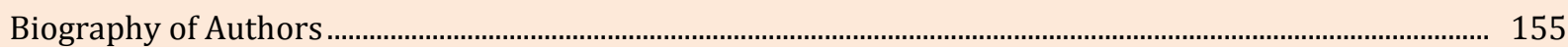

\section{Introduction}

in students is becoming frequent in recent years, and this happens due to the lack of attention of parents towards their children, it is due to various factors such as family breakdown, distance from home to the institution, inadequate food, helping their parents in agricultural work due to the economic situation they present spend most of their time in various occupations and long working hours are forced to neglect their children, this causes Do not help or collaborate to solve children's learning problems.

The term learning problem has been developing in recent decades, where countless ideas and interpretations have been generated that have been reflected in articles, constituting a vast field of discussion and research studies (Astawa et al., 2017; Iriani et al., 2018).

At present, there has been an increase in the debate that has brought with it new challenges that refer to a heterogeneous group of disorders, manifested by significant difficulties in the acquisition and use of the ability to understand, speak, read, write, reason or for mathematics. These disorders are intrinsic to the human being, and presumably due to a dysfunction of the nervous system, being able to continue throughout the vital process.

Efforts have focused on achieving the systematization of the study on learning disorders are an increasingly frequent reason for being part of the so-called new morbidity when referring to a different type of consultation. In our society, called knowledge, frequent learning problems must be addressed in time to ensure the personal and social success of the child to adapt the instruments and objectives of the study to the socio-cultural contexts where they develop, problems are It is important to have a working instrument that adapts to the conditions of the local reality.

Considering the characteristics of the environment, learning difficulties occur in childhood more frequently than previously thought, but due to various circumstances, they are diagnosed in certain occasions late or not detected, since it is recurrent to observe parents of children, young people who attend to consultations with psychologists because children have a learning problem in school, they also report that the same thing happened to them, but that parents, teachers did not know how to help them and do not want the same to happen to their children (Mateos, 2011).

\section{Materials and Methods}

A bibliographic review was used as a scientific method to determine the behavior of students in learning, in addition to performing the observation with the objective of carrying out actions that support this process in the school.

\section{Results and Discussions}

One of the main difficulties we face when addressing the issue of the learning problem is that there is no consensus criterion that delimits the issue because it is very broad this issue that includes perceptual problems to learning problems Basics such as literacy or mathematics. For this reason at present, educational institutions are concerned about the emergence of various learning problems that affect students who have tried to approach with different approaches by teachers that have allowed them to understand and understand them to detect them in time.

Therefore, learning as a mediating process based on reciprocal interaction, between biological, cognitive, emotional, environmental and behavioral aspects, which are internalized by the subject through significant 
experiences, socio-culturally contextualized where teachers must prepare for address the problems that students present in the classroom. Learning as a relatively permanent change in the behavior of an animal or human organism caused by experience (Tenecela, 2014).

It is considered that the study of learning problems cannot be done outside the socio-cultural context in which institutions develop Your work Students who do not learn are those who fail to master certain content or skills that have been established in the plans issued by the central plant and subsequently selected by teachers at the institutional level (Macías et al., 2018; Mahendra, 2016).

The educational institutions accentuate the socio-cultural and economic differences that young people present when they enter them, with the aggravating factor that adolescents who come from less favored sectors also attend less-implemented schools, which does not allow to compensate for a sufficient initial development. From these perspectives, learning difficulties have been a severe and frequent problem for educators, parents, and students who do not achieve school performance according to expectations, since the current school system needs to be prepared to successfully face the problem. Teaching of adolescents with notorious socio-emotional and socio-cultural deficiencies, in relation to young people who do not have learning disabilities

\subsection{Learning problems}

In order to define what learning disorders are, we must bear in mind that each individual has their own rhythm to assimilate learning. In any classroom of healthy children, endowed with an intelligence within the range of normality, we find different types of children: brilliant, who learn and assimilate concepts quickly and easily; They learn at the expected pace and finally there are children with learning problems who have persistent and serious problems to assimilate certain academic concepts (Suryasa et al., 2017).

It is the persistent, unexpected and specific inability to efficiently acquire certain academic skills (be it reading, writing, calculation, drawing, etc.), and that occur even though the child has normal intelligence, follows adequate schooling and its socio-cultural environment is favorable (Màlaga, 2010).

To deal with learning problems with relevance, it is necessary to raise the levels of understanding and experience of their conceptions and practices respectively, therefore, knowledge of various approaches leads to the application of greater tools depending on the diversity of learning difficulties that can be presented, it should be borne in mind that each learning difficulty will be different from another, even when it is presented in another student, which requires that teachers have a high level of preparation and experience in care to learning problems that arise in students.

Considering the concepts expressed, it is concluded that learning problems group a series of disorders that manifest themselves in significant difficulties in the acquisition and use of reading, writing, reasoning, mathematics and the reality of the classroom allows us to see that students continue to exist that continue without accessing or appropriating the lessons raised by the school.

\subsection{Causes of learning problems There}

There are several causes that can significantly interfere with learning. These can be caused not only by emotional problems but also cognitive, sensory or specific problems that can result in the loss of the school year. Differentiating these factors is not easy, so it is important that parents acquire a commitment to responsibility working together with teachers. Although in many cases the causes of learning problems are unknown, several authors express that they are the result of an abnormality in the structure and functioning of the brain or central nervous system. In the document deficiencies of language in pedagogical bases of special education, it has been possible to show several causes, which are presented below (Perez, 2005).

These are injuries in any of the systems or organs involved in the expression and production of language Figure 1 shows the organic causes of learning problems:

Martinez, C. J. B., Vasquez, B. S. G., Martinez, M. E. M., \& Gámez, M. R. (2019). Learning problems on educational context for cascol parish. International Journal of Social Sciences and Humanities, 3(2), 145-155. https://doi.org/10.29332/ijssh.v3n2.306 


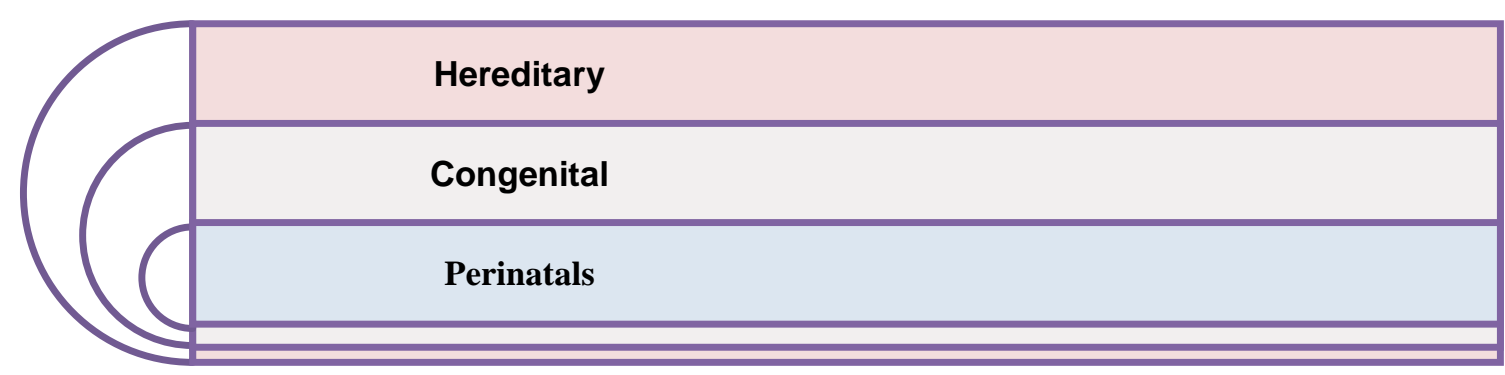

Figure 1. Organic causes of learning problems

\section{Causes of functional type}

They are due to a pathological functioning of the organs involved in the emission of language. An example would be a dysphasia of expressive content.

Organic-functional causes

Although most of the time, when the organ is affected, so is the function, it can happen that only the function is altered and the organ is not. This is what has called dysfunction.

Endocrine causes

They fundamentally affect the psychomotor development of the child, but they can also affect his affective development, language, and personality.

Environmental causes

They refer to the family, social, cultural, natural environment of the child, how to influence their emotional and development.

Psychosomatic causes

Thought can cause an anomalous oral expression, and word disorders can affect thinking. All these clouds the ability of good expression and understanding.

It is important to consider the majority of scientists, psycho-pedagogues agree that there is a wide range of possible causes of learning difficulties such as economic, social, emotional conditions but they can also be cognitive, sensory are varied and can improve or decrease the ability students have to learn

\subsection{Factors for detecting learning problems in Higher Basic General Education and Unified General Baccalaureate School}

Life is an important part of a student's life. The state of health, the structure of their personality and the environment will depend on whether they can achieve a good adaptation in educational institutions. That is why the factors that influence learning difficulties must have considered, these factors coexist, that is, they act on each other, and there may be a predominance of one over another. Table 1 the factors observed to detect learning problems presented in upper basic education and general baccalaureate unified

Table 1

Factors to detect learning problems

\begin{tabular}{|c|c|c|c|c|c|}
\hline $\begin{array}{l}\text { Factors to detect } \\
\text { learning } \\
\text { problems }\end{array}$ & Language & Mathematics & Motor & Care & \begin{tabular}{|l} 
Social Skill \\
\end{tabular} \\
\hline $\begin{array}{l}\text { Basic Education } \\
\text { Superior } \\
\text { General }\end{array}$ & $\begin{array}{l}\text { - Difficulty to } \\
\text { learn the } \\
\text { correspond } \\
\text { ence } \\
\text { between } \\
\text { sounds. }\end{array}$ & $\begin{array}{l}\text { - Problems to } \\
\text { learn the } \\
\text { time or } \\
\text { count } \\
\text { money. } \\
\text { - Confusion of } \\
\text { mathematica } \\
\text { l signs }\end{array}$ & $\begin{array}{l}\text { - Torpeza, poor } \\
\text { motor } \\
\text { coordination. } \\
\text { - Difficulty } \\
\text { copying on } \\
\text { the board. }\end{array}$ & $\begin{array}{l}\text { - Difficulties to } \\
\text { concentrate } \\
\text { on a task. } \\
\text { - Difficulties to } \\
\text { finish a job on } \\
\text { time. }\end{array}$ & $\begin{array}{l}\text { - Difficulty in } \\
\text { understanding } \\
\text { gestures or } \\
\text { facial } \\
\text { expressions. } \\
\text { - Difficulty to } \\
\text { understand } \\
\text { social }\end{array}$ \\
\hline
\end{tabular}




\begin{tabular}{|c|c|c|c|c|c|}
\hline & $\begin{array}{l}\text { - Errors } \\
\text { reading. } \\
\\
\text { - Difficulty } \\
\text { rememberin } \\
\text { g basic } \\
\text { words }\end{array}$ & $\begin{array}{l}\text { - Transposition } \\
\text { in the } \\
\text { writing of } \\
\text { figures } \\
\text { - Problems to } \\
\text { memorize } \\
\text { mathematica } \\
\text { l concepts } \\
\text { - Problems to } \\
\text { understand } \\
\text { the position } \\
\text { of numbers } \\
\text { - Difficulties to } \\
\text { remember } \\
\text { the steps of } \\
\text { mathematica } \\
\text { l operations. }\end{array}$ & $\begin{array}{l}\text { - Difficulty to } \\
\text { align the } \\
\text { figures in a } \\
\text { mathematical } \\
\text { operation. } \\
\text { - Poor writing }\end{array}$ & $\begin{array}{l}\text { - Inability to } \\
\text { follow } \\
\text { multiple } \\
\text { instructions. } \\
\text { - Careless, } \\
\text { carefree. } \\
\\
\text { - Rejection of } \\
\text { routine } \\
\text { changes or } \\
\text { new concepts }\end{array}$ & $\begin{array}{l}\text { situations. } \\
\text { - The tendency } \\
\text { to } \\
\text { misunderstand } \\
\text { peer or adult } \\
\text { behaviors. } \\
\text {-Apparent lack } \\
\text { of «common } \\
\text { sense» }\end{array}$ \\
\hline $\begin{array}{l}\text { Unified General } \\
\text { Baccalaureate }\end{array}$ & $\begin{array}{l}\text { - Avoid } \\
\text { reading or } \\
\text { writing } \\
\text { - The trend to } \\
\text { lose } \\
\text { information } \\
\text { when } \\
\text { reading a } \\
\text { text } \\
\text { - Poor reading } \\
\text { comprehensi } \\
\text { on, difficulty } \\
\text { understandi } \\
\text { ng the topics } \\
\text { read } \\
\text { - Poverty in } \\
\text { oral and/or } \\
\text { written } \\
\text { writing } \\
\text { - Difficulty in } \\
\text { learning } \\
\text { foreign } \\
\text { languages - } \\
\end{array}$ & $\begin{array}{l}\text { - Difficulties to } \\
\text { understand } \\
\text { abstract } \\
\text { concepts. } \\
\text { - Poor ability } \\
\text { to apply } \\
\text { math skills }\end{array}$ & & $\begin{array}{l}\text { - } \begin{array}{l}\text { Difficulties to } \\
\text { organize. }\end{array} \\
\text { - Problems in } \\
\text { multiple- } \\
\text { choice tasks. } \\
\text { - Slow work in } \\
\text { class and } \\
\text { exams. } \\
\\
\text { - Poverty when } \\
\text { taking notes. } \\
\text { - Poor ability to } \\
\text { correct your } \\
\text { work. }\end{array}$ & $\begin{array}{l}\text { - Difficulty } \\
\text { accepting } \\
\text { criticism. } \\
\text {-Problems to } \\
\text { negotiate. } \\
\text { Difficulties in } \\
\text { understanding } \\
\text { the point of } \\
\text { view of other } \\
\text { people }\end{array}$ \\
\hline
\end{tabular}

\subsection{Types of learning}

Disorders or problems School learning disorders or problems are disorders that, from the early stages of development, normal forms of learning are impaired. The deterioration arises from alterations in cognitive processes, largely secondary to some type of biological, dysfunction is more frequent among men, it is modified with age.

Learning problems, if not detected in time, are not diagnosed correctly and they are not treated effectively expose the student to repeated failed experiences, they can reduce the motivation for learning and favor the appearance of associated problems that affect the student's self-esteem and emotional well-being. Of course, if Martinez, C. J. B., Vasquez, B. S. G., Martinez, M. E. M., \& Gámez, M. R. (2019). Learning problems on educational context for cascol parish. International Journal of Social Sciences and Humanities, 3(2), 145-155. 
there are early detection and appropriate special intervention, most students can overcome or learn to correct learning problems that may have occurred.

\section{Dysgraphia}

Dysgraphia is a functional disorder that disturbs writing, thus making it difficult the normal development of the teaching-learning process. The letter of the dysgraphic child is characterized by its lack of readability since its graphics are composed of large, inclined, deformed, excessive or little spacing between letters, words or lines, undue links between graphemes, unrecognizable letters and, ultimately, writing difficult to understand (Ortiz, 2015).

Obviously, the dysgraphia is a difficulty that has based on the brain and is not the result of a child being idle simply holding a pencil and organizing the letters in a line is very difficult, his writing tends to be messy, spelling is more complicated and slower. Without help, a child with dysgraphia will have difficulties in all school activities.

Causes of dysgraphia. In Figure 2, three causes generate dysgraphia:
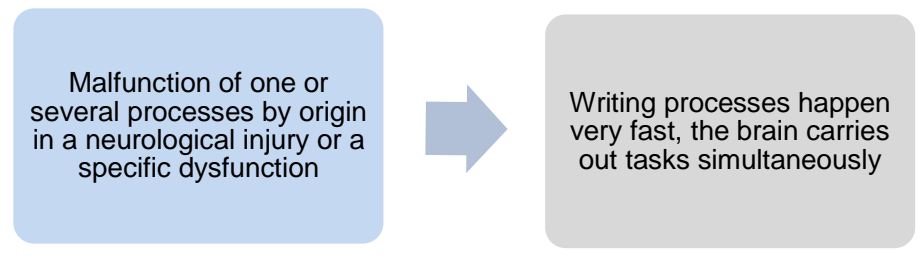

Figure 2. Causes of dysgraphia
The person cannot generate or does not have the information. Students are not used to telling

stories or describing facts or events.

\section{Dyslexia}

Dyslexia is a problem that affects the most vulnerable population and, if left untreated, can persist over time. Dyslexia in this sense is the difficulty in interpreting or generating languages, that is, the ability to read and write occurs in children with a normal IQ in which no physical or psychological problems appear (Castillo, 2011).

It is important to consider that dyslexia usually manifests between six and eight years, a period in which the child is learning to read and write with difficulty makes many mistakes such as omissions, distortions, slow performance, failure to understand, speed and precision. They need to has understood and helped timely by teachers and parents so they can continue their studies.

\section{Treatment}

Dyslexia in this regard, the treatment must be individualized and with spatial exercise with teachers and parents. Thus, the activity will begin with the marking of the error each time the student commits it, in order to correct the following exercises: rhythm, visor motor coordination, mastery of the body scheme, language, laterality, literacy, spatial and temporal structuring.

\section{Dysortography Dysortography}

Refers to the significant difficulty in transcribing the written code inexactly, that is, to the presence of great difficulties in the association between the written code, the spelling rules and the writing of the words. In this way, the difficulties lie in the association between sound and spelling or in the integration of spelling regulations, or in both aspects (Ramirez, 2010).

Dysortography is, therefore, the inability of the student to write properly, promoting the disorder of writing in learning to address this problem and be willing in addition to professionally prepared to solve it is one of the fundamental objectives of teachers 
Causes

Figure 3 shows five causes that generate dysortography in students
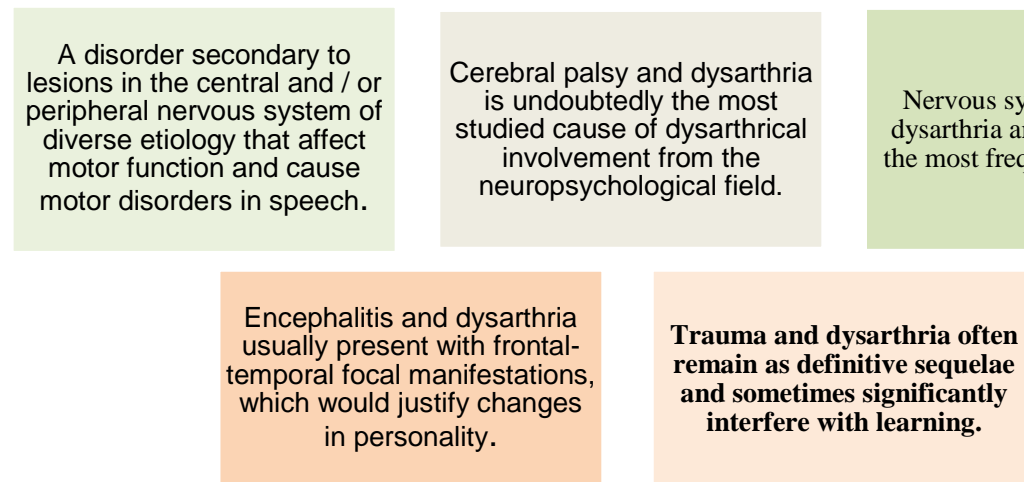

Figure 3. Causes that cause dysortography

\section{Dyscalculia}

Dyscalculia is one of the main learning problems identified as a difficulty in learning basic arithmetic skills those impacts on the level of school performance and activities of daily life. DD is a disorder of primary and specific neurodevelopment ... it is not secondary to an intellectual or sensory deficit nor to the lack of educational opportunities or an adverse family environment (Torresi, 2018). In this way, it is without a place to Doubt that dyscalculia is a deficit of oral, written and symbolic language that presents a deficit in calculating, difficulty in handling symbols, difficulty in reasoning logically and difficulty in developing arithmetic processes for problem-solving.

\section{Treatment}

Insinuations the reeducation of dyscalculia should have approached from a global perspective that has the support of family members and teachers. The intervention in the adolescent child will depend on the age and, among other aspects, which are set out below (Sans, 2017). In Figure 4, several treatments should have performed with students who have dyscalculia.

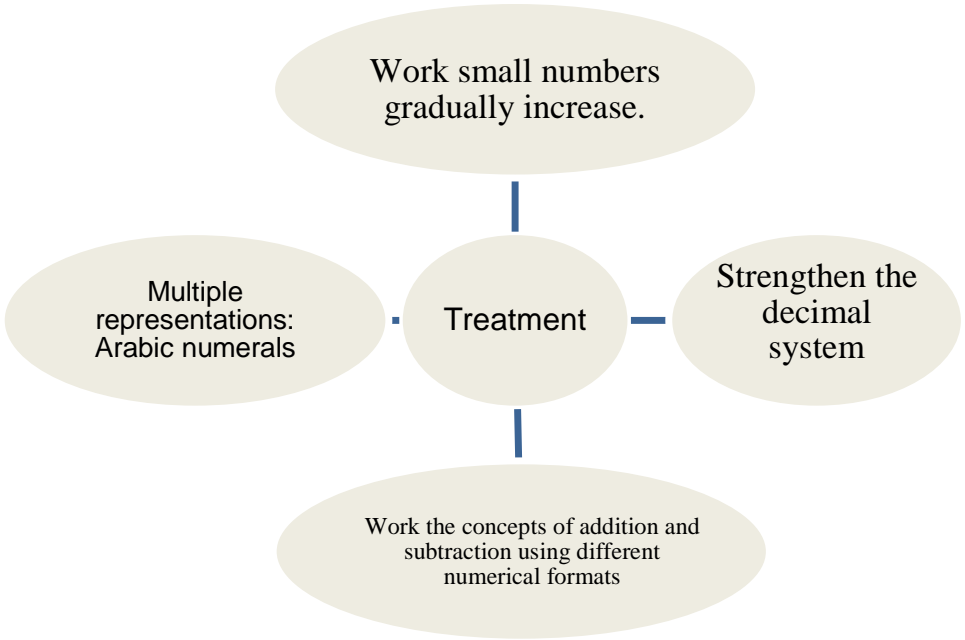

Figure 4. Treatment of dyscalculia

Martinez, C. J. B., Vasquez, B. S. G., Martinez, M. E. M., \& Gámez, M. R. (2019). Learning problems on educational context for cascol parish. International Journal of Social Sciences and Humanities, 3(2), 145-155. https://doi.org/10.29332/ijssh.v3n2.306 


\section{Dislalia}

The dislalia will be located in the process of language expression as a symptom, it will always be a problem referred to the articulation of the spoken word, and as such, to the process of language expression or speech. It is necessary to keep in mind that dyslalia is the alteration in the pronunciation of one or several phonemes by alteration, replacement or omission of them in people who do not have central neurological lesions or malformations in the phonoarticulatory organs. In these cases, early stimulation would be crucial to acquire the phonemic, lexicological and syntactic content of the language (Campos, 2014).

Dyslalia can affect any consonant or vowel, so the defect referred to a single phoneme or several in number can occur indeterminate, or affect only the association of consonants, when they appear united in a single syllable omitting, in this case, one of them. In figure 5, shows the classification of dislalia.

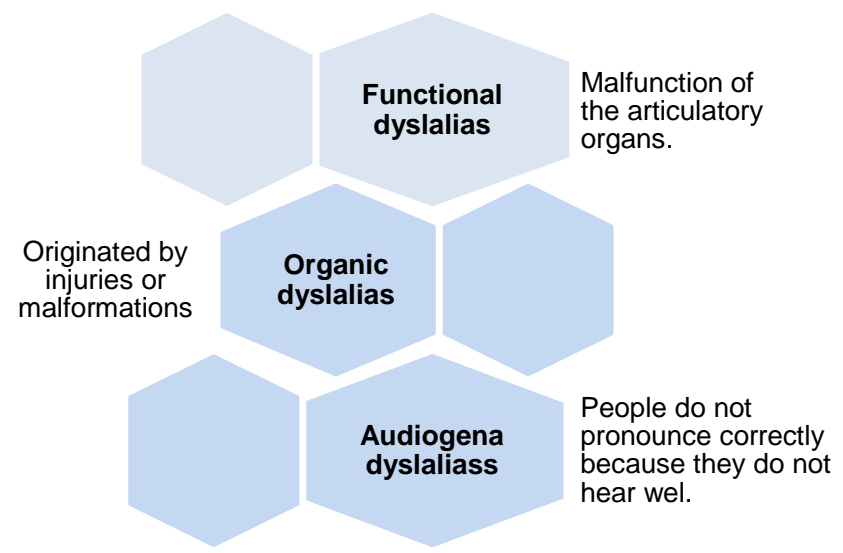

Figure 5. Types of dyslalias

\section{Hyperactivity}

They refer to subjects who present behavioral difficulties, which have characterized by lack of attention, constant motor motility, and impulsivity; characteristics that are generally associated with difficulties of an academic, affective and social nature.

Attention deficit hyperactivity disorder in school, children, adolescents occurs frequently, so it is important to consider the various risk situations and associated morbidities, which increase in proportion to the age at which the diagnosis is established, and between which highlights school difficulties and failures, oppositional behaviors, difficulties in interpersonal and family relationships, difficulties of adaptation and emotional disorders (Portela, 2016).

This disorder affects a number of children and youth has classified as a behavior disorder. It is characterized, hence its name, because children are hyperactive, impulsive and have trouble maintaining attention in a single activity on an ongoing basis. All this entails problems in school performance, as well as in their personal relationships with family, friends, and teachers. Learning difficulties refer to a group of alterations that manifest themselves in difficulties in acquiring and using language, writing, reasoning or mathematical skills. The alterations are intrinsic to the individual and have considered to has due to a dysfunction of the central nervous system. We must also remember that the problem is not in the child, not in their intellectual, psychofunctional, perceptual or motor skills. The problem is the lack of opportunities that students have to incorporate nature into the teaching-learning process.

Behavioral characteristics shown by children with ADHD, in figure 6 shows the characteristics of children with ADHD. 


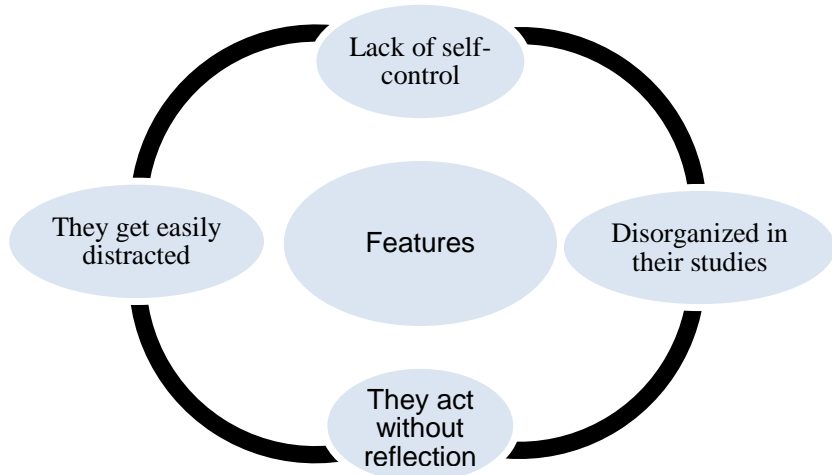

Figure 6. Behavioral characteristics are shown by children with ADHD

Learning problems in recent years have been increasing, more and more, and as we have seen, it is very important that they have detected in time for the complications that they can bring later in the school environment in the life of the teenager and even more important that it is properly attended.

Consequently, the research allowed us to know the learning problems that frequently occur in the educational environment of the Cascol parish. The lack of knowledge of the subject by teachers coupled. With the lack of interest from their families and direct representatives does not allow students to become aware of the serious problem that is getting worse with the passing of time causing an excuse to stop studying or live with qualifications that only allows you to spend the year but not obtain meaningful learning or for life.

\section{Conclusion}

To improve student's school performance, we must design teaching methods and strategies that help the student solve the different learning problems that our students have. Teachers in educational institutions have not properly trained to help children, adolescents who have difficulty in learning is a predominant factor for students to fail the year or drop out.

The Ecuadorian education system is not prepared to diagnose or treat students with psychic disorders such as dyslexia, dysgraphia, and dyscalculia. The demotivation by the study the low self-esteem, the school dropout in this type of student is one of the most notable consequences. At all levels of education, so it deserves an intervention from the departments of (UDAI) District Units of Support for Inclusion (UDAI) at the national level, with the objective of strengthening Specialized and Inclusive Education, and thus guaranteeing access, permanence, participation, and learning of children and young people with special educational needs associated or not with disability

\section{Acknowledgment}

The author would like to thank the editorial boards' team of IJSSH for their valuable time, support and advice in completing the present study.

Martinez, C. J. B., Vasquez, B. S. G., Martinez, M. E. M., \& Gámez, M. R. (2019). Learning problems on educational context for cascol parish. International Journal of Social Sciences and Humanities, 3(2), 145-155. 


\section{References}

Astawa, I. N., Handayani, N. D., Mantra, I. B. N., \& Wardana, I. K. (2017). Writing English language test items as a learning device: a principle of habit formation rules. International Journal of Social Sciences and Humanities, 1(3), 135-144. https://doi.org/10.29332/ijssh.v1n3.67

Campos, A. (2014). Pathologies of communication. Teaching project for child nursing. Dyslalias Scielo, 12(34), 444-452. Retrieved from http://scielo.isciii.es/scielo.php?script=sci_abstract\&pid=S169561412014000200020\&lng=es\&nrm=iso

Castillo, R. (2011). Reading dyslexia in children from 5 to 6 years of Leon Febres Cordero mixed tax school. (Bachelor thesis). Technical University of Babahoyo, Babahoyo, Ecuador. Retrieved from http://dspace.utb.edu.ec/bitstream/49000/1217/1/T-UTB-FCJSE-PARV-000053.pdf

Iriani, D. H., Syahdan, -, \& Nuriadi, -. (2018). The effect of early English learning on psychology. International Journal of Social Sciences and Humanities, 2(1), 65-74. https://doi.org/10.29332/ijssh.v2n1.82

Macías, EIP, Cedeño, HAC, \& Chávez, GMR (2018). Importance of Improving Resilience in Teaching-Learning Process of Students with Disabilities. International Research Journal of Management, IT and Social Sciences , 5 (2), 120-128.

Mahendra, I. W. E. (2016). Contextual learning approach and performance assessment in mathematics learning. International Research Journal of Management, IT and Social Sciences, 3(3), 7-15.

Màlaga, J. y. (2010). Learning disorders Definition of the different types of neurobiological bases. Bulletin of the pediatric society of Asturias, Cantabria, Castilla y León, 50, 43-47. Recovered from https://www.sccalp.org/documents/0000/1526/BolPediatr2010_50_043-047.pdf

Mateos, R. Y. (2011). Learning difficulties problem of late diagnosis and / or underdiagnosis. Inclusive Education Magazine, 4 (1), 103-11. $\quad$ Retrieved from http://www.ujaen.es/revista/rei/linked/documentos/documentos/12-7.pdf

Ortiz, J. (2015). Dysgraphia and its impact on the development of the learning of students in the sixth year of basic education of the educational unit árbol de vida. Salinas, (Bachelor thesis). Equinocial University. Quito, Ecuador. Retrieved from http://repositorio.ute.edu.ec/bitstream/123456789/16479/1/63891_1.pdf

Perez, JR (2005). Language Deficiencies: General causes that can cause a language disorder. Retrieved from https://previa.uclm.es/profesorado/ricardo/alumnoEE/LENGUAJE2005.doc

Portela, A. C. (2016). Attention deficit hyperactivity disorder some considerations about its pathogenesis and treatment. Scielo, 20 (4), 553-563. Retrieved from http://scielo.sld.cu/scielo.php?script=sci_abstract\&pid=S1029-30192016000400016

Ramirez, C. (2010). What is dysortography? Digital Magazine for teaching professionals, 9, 1-10. Recovered from https://www.feandalucia.ccoo.es/docu/p5sd7368.pdf

Sans, A. B. (2017). Learning disorders School learning disorders unit, neurology service hospital Sant Joan de Deu Esplugues Barcelona. Integral Pediatrics, 21 (1), 23-31. Recovered from https://www.adolescenciasema.org/ficheros/PEDIATRIA\%20INTEGRAL/Trastorno\%20del\%20Aprendiz aje.pdf

Suryasa, I. W., Prayoga, I. G. P. A., \& Werdistira, I. W. A. (2017). An analysis of students motivation toward English learning as second language among students in Pritchard English academy (PEACE). International Journal of Social Sciences and Humanities, 1(2), 43-50. https://doi.org/10.29332/ijssh.v1n2.36

Tenecela, J. Y. (2014). Incidence of learning difficulties (dixlesia and dyscalculia) in students from third to seventh year of basic general education. (Bachelor thesis), University of Cuenca, Cuenca, Ecuador. Retrieved from http://dspace.ucuenca.edu.ec/bitstream/123456789/20328/1/TESIS.pdf

Torresi, S. (2018). Developmental dyscalculia (DD). Psychopedagogy Magazine, 35 (108) 348-356. Recovered from http://pepsic.bvsalud.org/scielo.php?script=sci_arttext\&pid=S0103$84862018000300010 \& \operatorname{lng}=$ pt\&nrm=iso 


\section{Biography of Authors}

\begin{tabular}{|c|c|}
\hline & $\begin{array}{l}\text { Carlos Julio, } \\
\text { Bachelor of Education Science Mention Social Sciences in Universidad Tecnológica } \\
\text { Equinoccial De Quito, Teacher in Innovation in the education of the Pontificia } \\
\text { Universidad Católica Del Ecuador, Manabí, Teacher, Rector of the Fiscal } \\
\text { Educational Unit Cascol Cantón Paján Province of Manabí, President of the } \\
\text { Academic Council of the Circuit of Cascol C06 } \\
\text { Email: carlos2210@yahoo.com }\end{array}$ \\
\hline & $\begin{array}{l}\text { Brenda Stefania, } \\
\text { Agribusiness Engineer at the Eloy Alfaro De Manabí Lay University, Master in } \\
\text { Innovation in Education at the Pontificia Universidad Católica Del Ecuador, } \\
\text { Manabí, professor at the Cascol Cantón Paján Fiscal Education Unit in the province } \\
\text { of Manabí. } \\
\text { Email: brenda.guale@educacion.gob.ec }\end{array}$ \\
\hline & $\begin{array}{l}\text { Maria Elena, } \\
\text { Master in Pedagogy, Master in Management and Educational Leadership, Specialist } \\
\text { in Management and Educational Leadership, Diploma in Innovative Pedagogies, } \\
\text { Bachelor in Chemistry and Biology, Director, Rector and Vice-Rector of important } \\
\text { Educational Units of the city of Quito, a teacher trainer at the national level, } \\
\text { Editorial Director and book writer for Senderos Ediciones. University professor, } \\
\text { Director of Teaching and currently Coordinator of the Master Program in } \\
\text { Innovation in Education and Postgraduate Director of the Pontificia Universidad } \\
\text { Católica del Ecuador. } \\
\text { Email: mmoya@pucem.edu.ec }\end{array}$ \\
\hline & $\begin{array}{l}\text { Maria, } \\
\text { Bachelor of Education, Specialty: Physics and Astronomy, MSc. Planning and } \\
\text { Territorial Development (Strategic Planning Renewable sources of energy). Dra. } \\
\text { Strategies and Planning of the territory in Renewable Sources of Energy. } \\
\text { Professor-Researcher Evaluator of the CYTED and Colciencia program. Evaluator } \\
\text { of the Scielo Ecuador magazines. Expert in Energy Renewable Energy programs. } \\
\text { Pair evaluator of different international magazines. Author of several books, } \\
\text { scientific articles in academic journals, monographs, national and international } \\
\text { events, is directed the project: Una geoweb, for sustainable development in the } \\
\text { province of Manabí, approved in the UTM. } \\
\text { Email: mariarodriguez@utm.edu.ec }\end{array}$ \\
\hline
\end{tabular}

Martinez, C. J. B., Vasquez, B. S. G., Martinez, M. E. M., \& Gámez, M. R. (2019). Learning problems on educational context for cascol parish. International Journal of Social Sciences and Humanities, 3(2), 145-155. https://doi.org/10.29332/ijssh.v3n2.306 